\title{
KAJIAN DAMPAK NEGATIF APLIKASI BERBAGI VIDEO BAGI ANAK-ANAK DI BAWAH UMUR DI INDONESIA
}

\author{
Trie Damayanti, Ilham Gemiharto \\ trie.damayanti@unpad.ac.id; ilham265@gmail.com \\ Universitas Padjadjaran
}

\begin{abstract}
This study focuses on the phenomenon of video sharing applications that are currently plaguing the public through one of the smartphone-based applications with the Android and iOS operating systems, Tik Tok. The enthusiasm of the Indonesian people for video sharing applications that use 4G-LTE connectivity is very large. This application allows users or hosts to display video recordings of their users. For celebrities, video sharing applications help them greatly in increasing their popularity in the community. But this application is also vulnerable to being misused by some users to display pornographic nuances, giving rise to many concerns, especially among educators and religious scholars. This study uses qualitative research methods with data collection techniques using observation, in-depth interviews, and document studies as well as descriptive data analysis techniques, with research informants being the Tik Tok application users and several related parties. The formulation of the problem of this research is how the impact of the use of Tik Tok video sharing application on underage children in the city of Bandung. The results show that the Tik Tok video sharing application has many gaps that pose a danger to underage children. Among them is loose age control for users. By using a telephone number, Gmail or Facebook account, users can already display their video recordings through this application. This provides an opportunity for underage children to watch pornographic nuances in the application. The government through the Ministry of Communication and Information as a policy maker in the ICT field has tried to regulate access to Tik Tok video sharing applications through temporary blocking actions.
\end{abstract}

Keywords: Social Media, Video Sharing Application, Tik Tok, Children, Bandung City

\begin{abstract}
ABSTRAK
Penelitian ini memusatkan perhatian kepada fenomena aplikasi berbagi video yang saat ini tengah mewabah di kalangan masyarakat melalui salah satu aplikasi berbasis telepon pintar dengan sistem operasi Android dan iOS, yaitu Tik Tok. Antusiasme masyarakat Indonesia terhadap aplikasi berbagi video yang menggunakan konektivitas 4G-LTE ini sangat besar. Aplikasi ini memungkinkan pengguna atau host menayangkan rekaman video penggunanya. Bagi kalangan selebritis, aplikasi berbagi video sangat membantu mereka dalam meningkatkan popularitas dirinya di masyarakat. Namun, aplikasi ini juga rentan disalahgunakan oleh sebagian pengguna untuk menampilkan tayangan bernuansa pornografi, sehingga menimbulkan banyak kekhawatiran banyak pihak, khususnya kalangan pendidik dan alim ulama. Penelitian ini menggunakan metode penelitian kualitatif dengan teknik pengumpulan data menggunakan observasi, wawancara mendalam, dan studi dokumen serta teknik analisis data deskriptif, dengan informan penelitian adalah para pengguna aplikasi Tik Tok dan beberapa pihak terkait. Rumusan masalah penelitian ini adalah bagaimana dampak penggunaan aplikasi berbagi video Tik Tok terhadap anak-anak di bawah umur di kota Bandung. Hasil penelitian menunjukkan bahwa aplikasi berbagi video Tik Tok memiliki banyak celah yang menimbulkan bahaya bagi pengguna berusia anak-anak di bawah umur. Diantaranya adalah kontrol usia yang longgar bagi pengguna. Dengan menggunakan nomor telepon, akun Gmail atau Facebook, pengguna sudah bisa menayangkan rekaman video dirinya melalui aplikasi ini. Hal tersebut memberikan kesempatan kepada anak-anak di bawah umur untuk menonton tayangan bernuansa pornografi dalam aplikasi tersebut. Pemerintah melalui Kemenkominfo sebagai pembuat kebijakan dalam bidang TIK sudah berupaya mengatur akses terhadap aplikasi berbagi video Tik Tok melalui tindakan pemblokiran sementara.
\end{abstract}

Kata Kunci: Media Sosial, Aplikasi Berbagi Video, Tik Tok, Anak-anak, Kota Bandung.

PENDAHULUAN 
Teknologi LTE atau Long Term Evolution, lebih dikenal dengan sebutan teknologi 4G-LTE untuk membedakannya dengan teknologi 3G dan 3.5G, adalah teknologi terbaru komunikasi data nirkabel. Tujuan dari LTE adalah untuk meningkatkan kapasitas dan kecepatan jaringan data nirkabel yang telah dikembangkan pada awal milenium baru. Sistem antarmuka nirkabel 4G-LTE ini berbeda dengan jaringan $3 \mathrm{G}$ dan $3.5 \mathrm{G}$ sehingga harus dioperasikan pada spektrum yang terpisah. Koneksi internet dengan menggunakan teknologi 4G-LTE mampu mencapai kecepatan akses data untuk mengunduh (download) hingga 300 Mbps dan untuk menggunggah (upload) 75 Mbps. (Khan, 2009:66)

Pengertian berbagi video merupakan suatu teknologi komunikasi yang dilakukan melalui internet untuk mengirimkan video secara langsung (realtime). berbagi video mulai dikenal di Indonesia sejak munculnya teknologi $3 \mathrm{G}$ sekitar tahun 2008. Saat itu muncul media televisi di Indonesia yang menggunakan teknologi video streaming. Teknologi video streaming merupakan teknologi yang mampu menyampaikan informasi dalam bentuk tampilan video secara langsung. (Ero, 2009:30)

Teleconference merupakan salah satu bentuk komunikasi yang menggunakan berbagi video. Presiden Joko Widodo pernah melakukan komunikasi jarak jauh dengan masyarakat di berbagai pelosok tanah air melalui teleconference. Melalui penggunaan teknologi ini biaya transportasi dapat ditekan karena Presiden tidak perlu mengunjungi secara langsung daerah tersebut untuk menyampaikan pesanpesan pembangunan. Syaratnya adalah tersedianya bandwidth (lebar pita akses internet) yang memadai, agar proses berbagi video tidak terganggu.

Dengan munculnya teknologi 4G-LTE di Indonesia pada tahun 2015, kualitas tayangan berbagi video menjadi semakin lancar dan tanpa jeda (buffering). Bahkan kini berbagai aplikasi berbagi video sudah tersedia bagi pengguna telepon pintar (smartphone). Dimulai dari aplikasi Skype, Facebook Live, kemudian ada juga aplikasi BigoLive dan NonoLive. Yang terbaru dan tengah digandrungi oleh masyarakat adalah aplikasi yang menggabungkan media sosial dan berbagi video, yaitu Tik Tok. Sebetulnya saat ini sudah banyak aplikasi serupa Tik Tok, seperti Holla, Tamago, Kwai, Viva dan lain-lain. Namun, di Indonesia Tik Tok merupakan aplikasi berbagi video yang paling populer, karena kemudahan dan kepraktisan dalam penggunaannya. (Fauzi, 2017:44) 
Aplikasi berbagi video Tik Tok telah berhasil menggabungkan aplikasi media sosial, messaging dengan teknologi berbagi video. Banyaknya pengguna yang membagikan videonya dari berbagai negara di dunia menjadi salah satu tanda Tik Tok mendapat sambutan baik. Tik Tok pada awalnya didesain untuk mengakomodir para pengguna internet yang memiliki bakat seperti menyanyi, menari, memasak, dan lain sebagainya untuk bisa lebih dikenal melalui tayangan video. Dari catatan unduhan di Google Play saja, Tik Tok mendapat unduhan dengan total lebih dari 100 juta. Meskipun antusiasme konsumen lokal tinggi, potensi penyalahgunaannya tidak kalah besar. Sama seperti layanan media sosial yang lain, Tik Tok menyimpan potensi besar untuk hal-hal yang berbau seks dan pornografi. Beberapa rekaman siaran Tik Tok yang diunggah di YouTube dan beberapa situs lain tercatat memiliki konten yang bernuansa seks dan pornografi.

Beberapa oknum pengguna atau host memanfaatkan aplikasi ini untuk melakukan perbuatan amoral. Pengguna dapat dengan mudah masuk ke dalam aplikasi Tik Tok dan bebas memilih berbagai tayangan rekaman video pengguna yang sedang melakukan aksi tertentu, termasuk bisa memilih pengguna yang mengenakan pakaian seksi dan melakukan gestur yang tidak pantas.
Hal seperti ini, tentu tidak pantas dilihat oleh pengguna yang di bawah umur, yaitu remaja dan anak-anak.

Penelitian ini bermaksud untuk mengkaji dampak negatif aplikasi Tik Tok bagi pengguna di bawah umur, yaitu kalangan siswa Sekolah Dasar di kota Bandung. Diharapkan hasil penelitian ini dapat dijadikan pertimbangan bagi pihak terkait untuk membuat regulasi yang lebih ketat terhadap aplikasi berbagi video yang berpotensi negatif bagi remaja dan anak-anak, mengingat pemerintah Indonesia melalui Kemenkominfo yang terkenal reaktif terhadap konten negatif pernah melarang Tik Tok untuk mengudara di Indonesia, namun kemudian aktif kembali setelah melalui beberapa aturan pembatasan bagi pengguna.

Perkembangan teknologi komunikasi yang demikian pesat menjelang milenium baru telah menyebabkan terjadinya revolusi digital dengan terjadinya perubahan bunyi, gambar, dan teks dari format analog ke dalam format digital, yaitu format dapat dibaca oleh komputer. Perkembangan teknologi informasi turut memunculkan pula internet, atau interconnection networking yang telah membentuk ruang dan waktu baru, yang bersifat nirjarak, nirwaktu, yang disebut dengan cyberspace. Melalui internet dan cyberspace memunculkan konvergensi media, dimana media mengalami 
transformasi fungsi yang tadinya hanya sebatas suara tetapi sekarang telah menjadi saluran penting bagi informasi bunyi, visual, dan teks melalui internet. Kini umat manusia di muka bumi terkoneksi dengan internet, seperti neuron dalam sebuah otak raksasa. (Hawking, 1988:39).

Manusia selalu membutuhkan informasi untuk menjaga kelangsungan hidupnya, dan untuk mendapatkan informasi tersebut manusia perlu berkomunikasi dengan cara mudah, cepat, akurat dan murah. Fenomena menjamurnya internet dan globalisasi di hampir semua bidang kehidupan manusia, dari sains dan teknologi sampai gaya hidup hampir seluruh masyarakat di belahan dunia telah menjadi simbol kemajuan sebuah peradaban manusia dunia masa kini. Salah satu pendorong adalah kemajuan teknologi yang berhasil mengintegrasi teknologi informasi dan teknologi multimedia.

Tidak dapat dipungkiri bahwa internet memberikan dampak positif bagi penggunanya. Pengiriman informasi yang cepat dan update melalui fasilitas-fasilitas internet dapat dimanfaatkan oleh para penggunanya selain untuk memperkaya pengetahuan serta wawasan. Seperti halnya fungsi teknologi sebagai alat bantu untuk mempermudah kehidupan manusia, maka perkembangan internet menimbulkan pertanyaan terhadap dampak negatif yang ditimbulkannya. Sebuah survey di Inggris terhadap ratusan pengguna internet pada tahun 2008 terhadap 500 pengguna internet, menunjukkan adanya relasi positif antara tingginya pengguna internet dengan sikap depresi dan introvert. (Weatherburn, 2008:25)

Interaksi manusia dengan dunia maya (cyberspace), seperti duduk di depan komputer, login ke internet, dan terus menerus menikmati sensasi yang diwujudkan dengan cara menatap layar ketika berselancar di dunia maya melalui konektivitas yang dibangun memunculkan apa yang disebut sebagai cyberculture. Internet tidak lagi hanya sekedar alat, namun lebih dari itu dirasakan sebagai suatu kebutuhan yang mutlak dalam kehidupan manusia.

Pada awalnya untuk mengakses internet, manusia memerlukan perangkat komputer yang terhubung dengan jaringan telepon, namun kini dengan sebuah telepon pintar, setiap orang dapat langsung berkomunikasi melalui jaringan internet. Sejak ditemukan oleh IBM pertama kali pada tahun 1992, perkembangan teknologi membuat telepon pintar saat ini bahkan tidak mempunyai tomboltombol, kecuali sebuah layar sentuh yang dapat disentuh dengan ujung jemari atau pena stylus. Kini dengan mengeluarkan uang sebesar satu juta 
rupiah atau bahkan kurang, siapa pun dapat memiliki sebuah telepon pintar kelas entry level dan langsung mengakses jaringan internet dan menggunakan aplikasi yang diinginkannya.

Seperti halnya pisau bermata dua, aplikasi dalam telepon pintar dapat digunakan untuk tujuan positif maupun negatif. Seperti halnya media sosial, apapun bentuknya, saat ini seolah sudah menjadi kebutuhan bagi pengguna internet. Media sosial dapat digunakan untuk tujuan yang positif seperti menyebarkan ilmu pengetahuan dan keterampilan melalui dunia maya. Namun, juga dapat digunakan sebagai alat untuk penyebaran fitnah, bahkan digunakan untuk melakukan kejahatan, seperti prostitusi, penipuan, perampokan, transaksi narkoba, spionase, dan lainlain.

Seperti yang telah diketahui bersama pertumbuhan Teknologi Informasi dan Komunikasi (TIK) telah mempengaruhi kehidupan masyarakat secara ekonomi, sosial, dan budaya. Informasi telah menjadi kekuatan utama dalam sendi kehidupan dan sumber kekuatan keberdayaan masyarakat. Dalam sebuah survey Teknologi Informasi dan Komunikasi (TIK) yang dilakukan oleh Pusat Penelitian dan Pengembangan Aplikasi Informatika dan Informasi Publik Badan Penelitian dan Pengembangan
Sumber Daya Manusia Kementerian Komunikasi dan Informatika Republik Indonesia pada tahun 2017, mencoba melakukan penelitian dengan mendata masyarakat Indonesia pada kepemilikan dan kesadaran keterpaparan pada TIK. Sebanyak 9419 responden yang tinggal di $51,24 \%$ pedesaan dan $48,76 \%$ di perkotaan, sebanyak $11,5 \%$ dari Kalimantan, $24,5 \%$ di Sumatera, 15,6\% Sulawesi, 30,6\% di pulau Jawa, 8,3\% di Bali dan. Nusa Tenggara, serta 9,5\% di Maluku dan Papua. Survei ini ingin mengetahui terkait dengan penggunaan, computer, laptop, handphone dan smartphone di kalangan masyarakat dan bagaimana mereka memanfaatkan internet dalam gawainya. Survei ini menunjukkan bahwa responden yang memiliki rentang usia 9-65 tahun adalah pengguna gawai aktif dari computer sampai dengan smartphone dan untuk selanjutnya untuk dikaitkan dengan penelitian ini akan lebih menitikberatkan pada pengguna smartphone. Survey ini menunjukkan bahwa $66,3 \%$ individu di Indonesia memiliki smartphone dan individu yang memiliki smartphone tersebut $83,04 \%$ tinggal di wilayah urban. Data ini menunjukkan lebih dari setengah masyarakat Indonesia terpapar informasi yang beredar melalui smartphone tersebut. Smartphone ini bisa dikategorikan 
sebagai sebuah gawai yang terkoneksi dengan internet dan ada dalam genggaman setiap saat. Berdasarkan usia 75,95\% berusia 20-29 tahun, tetapi yang berusia 9-19 tahun pun cukup signifikan, yaitu 63,34\%. Frekuensi dalam menggunakan smartphone sebanyak $34,51 \%$ adalah 1-3 jam meskipun 26,69\% menggunakan 3-5 jam setiap harinya. Berdasarkan pekerjaan pelajar/mahasiswa cukup banyak menggunakan smartphone ini, yaitu $70,98 \%$. Terpaan internet sebanyak $60,15 \%$ ada pada usia 20-29 tahun, sementara 43,90\% di usia 9-19 tahun. Masih berdasarkan survey tersebut penggunaan internet lebih dari 50\% digunakan untuk komunikasi dan interaksi, sisanya digunakan untuk web browsing, streaming, dan $e$ commerce, dan sedikit yang memanfaatkan untuk pencarian $e$ book. Dalam menggunakan internet $59,3 \%$ memanfaatkan wireless hotspot yang tersedia gratis di lingkungan sekitar dan 46,5\% menggunakan fixed line, yaitu jenis internet berlangganan, sisanya sebanyak 9,71\% menggunakan paket data telepon genggam untuk individu. (Survey Penggunaan TIK Kemenkominfo, 2017).

Perkembangan teknologi komunikasi, yaitu konektivitas 4GLTE telah membuat koneksi internet semakin cepat, mudah, dan murah. Salah satu aplikasi yang membutuhkan koneksi internet yang stabil adalah berbagi video, atau siaran langsung melalui video di internet. Dengan adanya teknologi 4G-LTE, maka aplikasi berbagi video dapat dilakukan tanpa adanya buffering sehingga dapat berlangsung mulus tanpa jeda.

Media sosial merupakan aplikasi yang berkembang seiring dengan perkembangan Teknologi Informasi dan Komunikasi ini. Media sosial ini bisa diartikan sebagai sebuah media yang bersifat online memanfaatkan internet sebagai alat penghubung yang mencoba menghubungkan satu orang dengan orang lain dalam waktu yang bersamaan meskipun dalam jarak yang cukup jauh. Fenomena media sosial ini mengembangkan suatu istilah yang dikenal di masyarakat, yaitu 'menjauhkan yang dekat dan mendekatkan yang jauh'. Fenomena ini dimanfaatkan oleh berbagai macam bidang dari hiburan, ekonomi, komunikasi, dan lain sebagainya bahkan media sosial ini menjadi salah satu yang berperan dalam perubahan masyarakat terutama dalam aspek sosial. Aspek sosial yang dimaksud ini adalah kesejahteraan sosial (social welfare), ikatan sosial (social bonding) dan sosial budaya (social culture). Hasil Survey TIK yang dilakukan oleh Kementerian Komunikasi dan Informatika Republik Indonesia pada tahun 2017 
menunjukkan bahwa $92,82 \%$ masyarakat Indonesia adalah pengguna media sosial dengan menggunakan berbagai macam akun tidak hanya dalam satu sosial media. Berdasarkan Pendidikan 97,5\% adalah SMA dan Diploma/S1. Jika melihat pada usia, usia 9-19 tahun berjumlah 93,52\%, usia 20-29 tahun $95,96 \%$ usia $30-49$ tahun $93,5 \%$ dan usia 50-65 tahun 80,32\%. Dari data itu terlihat bahwa generasi milenial yang berada di usia 20-29 tahun merupakan pengguna terbanyak. Di tahun 2017, sosial media yag paling banyak digunakan oleh kaum urban adalah Path, yaitu sebanyak $84,91 \%$, disusul dengan Twitter, Instagram dan Facebook, sementara pada kaum rural Facebook merupakan media sosial yang paling banyak digunakan $(33,23 \%)$ disusul dengan Instagram, Twitter dan Path. Tetapi semenjak Path dihapus di tahun 2018 ada kemungkinan kecenderungan penggunaan media sosial ini berubah. Survey juga menunjukkan bahwa durasi penggunaan media sosial ini oleh pelajar/mahasiswa sebanyak $47,06 \%$ adalah $1-3$ jam hanya $14,29 \%$ yang mengakui menggunakan selama 5-10 jam. Penelitian ini juga menemukan bahwa masyarakat dalam mempersepsikan TIK adalah sebuah teknologi yang mempermudah dalam mengakses informasi, tetapi mereka juga menyadari semakin mudah mendapatkan konten negative berupa konten judi, pornografi, terorisme, dan radikalisme. Masyarakat pun menyadari perlunya pendidikan yang tinggi dalam mencoba menyaring informasi-informasi atau kontenkonten negatif karena semakin tinggi pendidikan seseorang akan semakin sulit untuk mendapatkan terpaan konten negative karena sifatnya yang selalu mencoba mencari informasi yang benar. Survey ini menemukan bahwa responden di wilayah rural dan urban yang memiliki tingkat pendidikan rendah memiliki kecenderungan tidak melakukan penelusuran kebenaran informasi lebih lanjut. Meskipun tingkat pendidikan responden rendah, namun pengetahuan masyarakat urban sebanyak $62,5 \%$ menyadari adanya konten negative di internet. (Survey Penggunaan TIK Kemenkominfo, 2017).

Salah satu aplikasi yang menggabungkan antara berbagi video dengan media sosial dan permainan adalah aplikasi Tik Tok. Berbeda dengan aplikasi serupa lainnya, Tik Tok memungkinkan penggunanya untuk merekam, mengedit dan memberikan efek-efek menarik bagi video penggunanya.

Fenomena pemanfaatan media Tik Tok ini tentu memberikan dampak bagi penggunanya seperti yang disampaikan Bandura (1978) dalam teori besarnya yang disebut 
Teori Belajar Sosial, teori ini mengungkapkan bahwa manusia pada dasarnya memiliki kecenderungan meniru perilaku orang lain yang dipengaruhi oleh lingkungannya. Bandura meyakini bahwa manusia belajar dengan lingkungannya bahkan dalam bentuk penguatan 'secara tidak langsung' atau penguatan pengganti (vicarious reinforcement) artinya selain meniru perilaku orang lain juga perilaku yang bisa menguatkan perilaku individunya (Jarvis, 2007: 31).

\section{METODE PENELITIAN}

Penelitian mengenai fenomena aplikasi berbagi video Tik Tok yang saat ini tengah mewabah di kalangan remaja dan anak-anak ini menggunakan metode eksploratif, dimana menurut Kultar Singh (2007) yang disebut dengan penelitian eksploratif adalah penelitian yang berupaya memaparkan atau menggambarkan fenomena dimana peneliti belum memiliki arah atau peta penjelasan tentang fenomena yang dihadapinya. Eksploratif adalah semacam pengumpulan data untuk menjawab persoalan yang menjadi minat peneliti (Bajari, 2015: 36). Metode analisis penelitian ini yang digunakan adalah analisis studi kasus berdasarkan metode, data, dan triangulasi sumber. Sedangkan metode pengumpulan data dalam penelitian ini adalah melalui penelitian dokumen dan penelitian lapangan berupa obsevasi dan wawancara. Data yang dikumpulkan dalam penelitian ini terbagi menjadi data primer dan data sekunder. Data primer merupakan hasil observasi dan wawancara dengan 15 informan penelitian di lokasi penelitian, sementara data sekunder adalah data yang diperoleh dari situs-situs berita online (website), jurnal-jurnal komunikasi, serta buku-buku yang relevan dengan penelitian ini.

Berdasarkan asumsi-asumsi di atas, penelitian ini secara praktis berusaha untuk mengkaji peristiwa kehidupan yang nyata yang dialami oleh subjek penelitian ini secara holistik dan bermakna. Dalam uraian yang lebih lugas, penelitian ini berusaha untuk memberikan deskripsi dan eksplanasi terhadap fenomena penggunaan aplikasi Tik Tok di wilayah Kota Bandung sebagai pusat pemerintahan dan perekonomian Provinsi Jawa Barat.

Teknik analisis data yang digunakan dalam penelitian ini adalah mengacu pada konsep Miles \& Huberman (2012: 20) yaitu interactive model yang mengklasifikasikan analisis data dalam tiga langkah, yaitu Reduksi data (Data Reduction), Penyajian data (Display Data), dan Pengujian Keabsahan Data (Verifikasi). Untuk menguji keabsahan data yang didapat sehingga benar-benar sesuai dengan 
tujuan dan maksud penelitian, maka peneliti menggunakan teknik triangulasi. Triangulasi data adalah teknik pemeriksaan data yang memanfaatkan sesuatu yang lain di luar data tersebut untuk keperluan pengecekan atau sebagai pembanding data tersebut (Moleong, 2007: 330).

\section{HASIL DAN PEMBAHASAN}

Tik Tok diciptakan dan dikembangkan oleh Zhang Yiming, seorang lulusan software engineer dari Universitas Nankai, China yang mendirikan perusahaan teknologi informasi ByteDance pada bulan Maret tahun 2012. Awalnya ByteDance meluncurkan aplikasi berita, Toutiao yang kini menjadi salah satu yang terbesar di Cina. Hingga kemudian tren membuat Zhang Yiming memutuskan untuk merambah aplikasi media sosial yang lebih interaktif. Alasannya saat itu dalam industri konten, teks dan gambar telah berkembang menjadi video, dan konten kini banyak berasal dari pengguna. Tik Tok, suatu aplikasi berbagi video pendek, dibuat Zhang untuk menjawab kebutuhan pengguna yang belum terpenuhi oleh aplikasi yang ada saat ini. Aplikasi yang di negara asalnya dikenal dengan nama Douyin ini secara resmi diluncurkan pada bulan September 2016.

Banyaknya jumlah pengguna aktif dari masing-masing negara menjadi salah satu tanda Tik Tok mendapat sambutan baik di negaranegara tersebut. Tik Tok pada awalnya didesain untuk mengakomodir para pengguna internet yang memiliki bakat seperti menyanyi, menari, komedi, dan lain sebagainya untuk bisa lebih dikenal melalui tayangan live berkembang begitu pesat di kawasan Asia Tenggara. Dari catatan unduhan di Google Play saja, Tik Tok mendapat unduhan dengan total lebih dari 100 juta.

Tik Tok saat ini menempati posisi 10 besar aplikasi gratis terpopuler di Google Play Store di seluruh dunia, termasuk di Cina, Korea dan di Indonesia. Tik Tok dapat digunakan untuk menyiarkan aktivitas sehari-hari seorang pengguna ke pengguna Tik Tok lainnya. Pada halaman muka, pengguna akan disuguhkan dengan beragam video pengguna yang dapat ditonton. Untuk melihatnya, pengguna hanya perlu memilih salah satu dari mereka. (Ardian, 2017)

Aplikasi berbagi video Tik Tok menggunakan teknologi berbagi video singkat yang membutuhkan koneksi yang stabil. Tik Tok dapat diakses menggunakan konektivtas $3 \mathrm{G}$ atau HSDPA dan HSUPA (3.5G), namun untuk mendapatkan tayangan video yang lancar dan tanpa jeda (buffering), pengguna disarankan menggunakan konektivitas 4G-LTE. Dengan ketersediaan infrastruktur 
jaringan 4G-LTE di Indonesia semakin memudahkan para pengguna khususnya di kota-kota besar di Indonesia untuk mengakses aplikasi Tik Tok ini. (Hasan, 2017).

Dampak positif Tik Tok diantaranya banyak para pengguna yang menampilkan bakat-bakat mereka melalui aplikasi ini, mulai dari keahlian bernyanyi, menari, bahkan ada juga yang bernuansa Religius (seperti berdakwah dan mengaji). Salah satu akun pengguna Tik Tok yang memiliki banyak pengikut adalah akun nissasabyan, seorang penyanyi gambus pop berusia belia yang memiliki suara yang indah (Ardian, 2018)

Salah satu keistimewaan Tik Tok adalah pengguna dapat mengedit videonya sesuka hati dengan ribuan efek yang disediakan oleh aplikasi Tik Tok. Semakin kreatif pengguna dan semakin menarik video yang dihasilkan maka semakin banyak tanda like yang didapatkan. Seperti halnya media sosial lainnya, maka pengguna Tik Tok juga dapat menghasilkan banyak uang bagi penggunanya, seperti akun bowoalpenliebe yang sering mengadakan jumpa penggemar yang mengharuskan pengguna lainnya membayar sejumlah uang tertentu untuk dapat bersalaman dan berfoto bersama.

Tik Tok dapat didapatkan dengan cara mengunduh aplikasinya di AppStore atau Google Play Store. Dari halaman muka (homepage) pengguna akan melihat banyak thumbnail dari orang-orang yang telah mengunggah video rekamannya. Pengguna dapat melihat mereka mempertontonkan keahlian mereka seperti bernyanyi, menari, komedi, tutorial, tips dan trik, dan banyak hal lainnya, semua dapat diakses dengan mengklik salah satu video yang ada. Untuk mengganti video yang tengah diputar, cukup melakukan scroll ke atas atau ke bawah layar.

Pada bagian atas layar terdapat ikon untuk memilih pengguna tertentu. Ketika pengguna mengklik ikon tersebut maka akan muncul layar dimana pengguna dapat melakukan "search", "like" dan "follow" para pengguna favorit yang diinginkan dari berbagai negara dan wilayah, untuk kemudian pengguna akan menerima notifikasi secara langsung. Hanya dengan melakukan klik pada ikon kamera yang berada di homepage, pengguna dapat merekam video dan kemudian mengedit dan menambahkan efek. Selain itu pengguna dapat pula berinteraksi dengan teman-teman pengguna secara langsung. Pengguna dapat mengedit profil pengguna pada ikon orang yang berada di bagian atas homepage. Pengguna memiliki tingkat profil dimana semakin tinggi tingkat profil pengguna, maka pengguna akan mendapatkan lebih 
banyak perhatian dari para pengguna lain dan setiap orang yang melihat video pengguna.

Di Tik Tok semua orang dapat membagikan videonya, setiap orang dapat menunjukkan bakat dan berbagi ilmu dengan orang lain dalam bentuk video dan mengobrol secara langsung. Sudah banyak para pengguna favorit mulai dari kalangan artis hingga orang biasa yang memiliki keahlian tertentu menjadi lebih terkenal di dunia Tik Tok.

\section{A. Dampak Negatif Aplikasi Bigo Live Bagi Penggunanya} Tujuan awal dari aplikasi Tik Tok adalah menyalurkan bakat penggunanya untuk berbagi hobi, bakat dan keahlian kepada semua orang. Apabila dilihat tujuannya Tik Tok tidak berbeda dengan situs berbagi video YouTube. Namun, kelebihan Tik Tok yang tidak dimiliki YouTube adalah fitur berbagi video bagi penggunanya. YouTube sebetulnya juga memiliki channel (saluran) berbagi video, namun hanya disediakan bagi pengguna tertentu, bukan bagi semua orang. Berbagi video misalnya digunakan untuk siaran langsung pertandingan olahraga atau pemilihan presiden Amerika Serikat.

Saat ini setidaknya ada terdapat lebih dari 10 aplikasi berbagi video yang digunakan oleh masyarakat Indonesia. Namun, sepanjang bulan Juli-Agustus 2018, aplikasi berbagi video Tik Tok berada di posisi terbanyak diunduh dan dijalankan. Ibaratnya dua mata pisau, setiap teknologi memiliki dampak positif dan dampak negatif bagi penggunanya. Tak sedikit pihak yang diuntungkan dengan kehadiran aplikasi ini. Dari sisi pengguna, bisa memberikan informasi yang cepat secara real time saat kejadian berlangsung, bisa dimanfaatkan sebagai sarana edukasi dengan berbagai tutorial, digunakan untuk konser musik, bahkan bisa menjadi sumber penghasilan. Operator selaku penyedia jaringan tentu menyambut baik hadirnya layanan ini. Karena konsumen semakin boros kuota data sehingga pendapatan dari sektor layanan data pun semakin meningkat.

Terlepas dari segala manfaat yang bisa diperoleh, bermunculan pula dampak negatif layanan berbagi video Tik Tok yang harus diantisipasi. Dampak negatif ini sebagian bisa dikontrol dengan mudah, namun sebagian lagi sangat sulit untuk dikendalikan, bahkan sudah sampai pada tahap mengkhawatirkan.

Dampak negatif yang paling banyak dikeluhkan oleh para orang tua yang memiliki anak remaja dan anak-anak, adalah adanya konten pornografi dalam aplikasi Tik Tok. Ketika masuk, pengguna dapat melihat video dimana seorang atau 
beberapa beraksi dan berinteraksi dengan pengunjung. Pengguna sendiri dapat mengirim pesan ke pengguna tertentu. Dari keseluruhan pengguna, sebagian besar dari mereka didominasi perempuan. Namun, terkadang para pengguna yang tampil berpakaian seksi dan terlihat menunjukkan bagian pribadi mereka ke publik.

Hal ini tentu sangat disayangkan, mengingat semua lapisan masyarakat dari beragam usia dapat menggunakan aplikasi ini secara gratis. Untuk menggunakan Tik Tok, pengguna hanya perlu menggunakan nomor telepon, namun apabila pengguna sudah memiliki akun Google, Facebook, Twitter. Tidak ada filter tertentu dalam aplikasi ini yang dapat digunakan mencegah remaja dan anak-anak menikmati konten untuk orang dewasa dalam aplikasi ini.

\section{B. Menyikapi Dampak Negatif Aplikasi Berbagi Video Tik Tok}

Antusiasme masyarakat yang demikian besar terhadap aplikasi berbagi video Tik Tok menimbulkan reaksi yang beragam dari berbagai kalangan. Untuk itu penelitian ini berupaya menemukan fakta yang objektif dan komprehensif mengenai aplikasi berbagi video Tik Tok sebagai upaya untuk menyikapi secara tepat perkembangan teknologi komunikasi saat ini dan mengantisipasi dampak yang ditimbulkannya.

Beberapa fakta di lapangan hasil wawancara secara mendalam terhadap narasumber dari kalangan pengguna aktif aplikasi Tik Tok ini, menunjukkan bahwa kekhawatiran terhadap dampak negatif aplikasi ini cukup beralasan. Dari 10 broadcaster yang diwawancarai, 8 (delapan) diantaranya menyatakan sudah pernah menyaksikan tayangan pornografi pada aplikasi Tik Tok. Hal ini menunjukkan bahwa tayangan pornografi di dalam aplikasi tersebut, sangat mudah untuk diakses oleh remaja dan anak-anak.

Sementara itu dari 8 (delapan) narasumber pengguna yang pernah melihat tayangan pornografi, 5 (lima) narasumber diantaranya menyaksikan tayangan pornografi lebih dari 3 (tiga) kali, bahkan salah seorang narasumber menyatakan menyaksikan tayangan pornografi setiap hari melalui aplikasi ini. Hal ini tentu saja sangat mengkhawatirkan karena di usia mereka yang masih belia.

Dari hasil wawancara dengan pihak narasumber dari kalangan pendidik (guru sekolah menengah atas), kedua narasumber menyatakan mengetahui akan adanya aplikasi berbagi video Tik Tok, namun hanya seorang narasumber yang sudah mengetahui adanya konten pornografi dalam aplikasi tersebut. Sementara 
kedua narasumber lainnya, menilai aplikasi Tik Tok tidak berbeda dengan situs berbagi video seperti YouTube atau aplikasi video streaming Bigo. Pencegahan yang dilakukan oleh pihak pendidik (guru) adalah dengan melarang penggunaan smartphone selama proses belajar mengajar di dalam kelas, maupun di dalam lingkungan sekolah. Apabila seorang siswa diketahui mengakses tayangan pornografi melalui situs atau aplikasi apapun, maka telepon genggamnya akan disita dan siswa yang bersangkutan akan dijatuhi sanksi mulai dari sanksi fisik hingga skorsing. Menurut narasumber dari pihak pendidik, biasanya para siswa mengakses aplikasi Tik Tok di luar jam sekolah, sehingga tidak dapat dipantau oleh mereka.

Sementara itu, 2 (dua) narasumber dari pihak orang tua siswa, menyatakan bahwa mereka sudah mengetahui akan adanya aplikasi Tik Tok yang saat ini tengah digandrungi oleh anak-anak mereka, khususnya yang masih di bawah umur. Seorang narasumber menyatakan anak perempuannya yang berusia 15 tahun mengakses aplikasi Tik Tok setiap hari. Namun, sejauh ini tidak menemukan hal-hal negatif seperti muatan pornografi dalam aplikasi tersebut. Aplikasi berbagi video seperti Tik Tok lebih banyak digunakan untuk menyalurkan hobi anaknya dalam bidang seni musik, olahraga, dan menari. Seringkali anaknya menciptakan lagu sendiri kemudian memainkannya dengan menggunakan alat musik keyboard yang ditayangkan secara live melalui aplikasi Tik Tok tersebut.

Sementara narasumber dari pihak orangtua lainnya mengaku pernah memergoki anak laki-lakinya yang berusia 11 tahun membuka konten negatif dari seorang pengguna dewasa di Jakarta. Narasumber tersebut kemudian sempat menyita smartphone anaknya selama seminggu dan dikembalikan setelah menghapus aplikasi Tik Tok tersebut. Narasumber tersebut juga berpendapat bahwa sudah waktunya pemerintah memblokir aplikasiaplikasi seperti itu karena lebih banyak dampak negatif daripada dampak positifnya. Bahkan narasumber tersebut menyatakan setuju dengan langkah Kemenkominfo memblokir aplikasi berbagai video Tik Tok yang dampak negatifnya jauh lebih besar bagi generasi muda.

Selain kedua orang tua tersebut, narasumber dari kalangan pemuka agama, yaitu seorang ustad muda yang memiliki perhatian kepada perkembangan generasi muda, secara tegas menyatakan bahwa aplikasi berbagi video seperti Tik Tok ini lebih banyak mudharat (bahaya) nya dibandingkan dengan 
manfaatnya. Selain itu, aplikasiaplikasi seperti Tik Tok bisa membuat anak kecanduan hingga melalaikannya dari melaksanakan ibadah harian seperti sholat lima waktu. Alangkah lebih baik jika pemerintah memblokir aplikasi yang banyak bahayanya seperti itu.

\section{SIMPULAN}

Dari pembahasan hasil penelitian yang telah dilakukan dalam penelitian ini, dapat diambil beberapa kesimpulan sebagai berikut:

Pertama, Tik Tok adalah aplikasi berbagi video yang selama setahun terakhir begitu diminati oleh masyarakat Indonesia, dan menempati posisi 10 besar dalam hal jumlah unduhan terbesar di Google Play Store di Indonesia selama tahun 2017-2018. Hal yang menarik minat masyarakat untuk menggunakan aplikasi ini adalah kemudahan dalam penggunaannya dan adanya fitur yang memungkinkan pengguna mendapatkan uang tunai jutaan rupiah dari aplikasi ini.

Kedua, Teknologi berbagi video dalam aplikasi Tik Tok membutuhkan kuota data internet yang sangat besar dan konektivitas data yang stabil dengan teknologi 4GLTE, sehingga cukup menghambat pengguna yang berada di kawasan dengan kualitas sinyal internet yang kurang baik.
Ketiga, Kekhawatiran dari kalangan pendidik dan pemuka agama terhadap dampak negatif dari aplikasi berbagi video dinilai pakar TIK sangat beralasan, karena batasan usia minimal yang sangat longgar untuk dapat mengakses aplikasi Tik Tok. Selain itu, kecenderungan pengguna atau pengguna Tik Tok yang menghalalkan segala cara misalnya dengan berpenampilan vulgar untuk mendapatkan like dari pengguna lainnya.

Keempat, Kalangan pendidik dan pemuka agama berpendapat bahwa aplikasi berbagi video Tik Tok dapat membahayakan mental dan moral kaum generasi muda khususnya anak-anak di bawah umur karena lebih banyak bahayanya dibanding manfaatnya, sehingga mengusulkan kepada Kemenkominfo untuk memblokir aplikasi tersebut secara permanen.

\section{DAFTAR PUSTAKA}

Ardian, Danang. 2018. Tik Tok, Aplikasi Berbagai Video yang Tidak Ada Manfaatnya. Jakarta: TechNews.

Bajari, Atwar. 2015. Metode Penelitian Komunikasi. Bandung: Simbiosa Rekatama Media

Denzin, Norman K. dan Guba, Egon. 2001. Teori dan Paradigma Penelitian Sosial; Pemikiran dan 
Penyunting: Agus Salim.

Yogyakarta: PT Tiara

Wacana.

Ero, J., 2015. Sistem Aplikasi Berbagi

Video. Yogyakarta: UGM.

Fauzi F., 2012. Analisis Penerapan

Teknologi Jaringan LTE $4 G$

di Indonesia. Bandung:

Institut Manajemen Telkom.

Hasan, Wahyu N., 2016. Inilah Dampak Negatif dari

Maraknya Layanan Video

Streaming. Jakarta: Arena 4GLTE.

Hawking, Stephen., 2014. Theory of Everything. London: Working Title.

Jarvis, Matt. Teori-Teori Psikologi. 2007: Bandung: Nusamedia.

Khan, Farooq. 2009. LTE For $4 G$ Mobile Broadband Air Interface Technologies And. Performance.

Boston:

Cambridge University Press.

Miles, Matthew B. dan Huberman, A. Michael. 2012. Analisis Data Kualitatif. Jakarta: Universitas Indonesia Press.
Moleong, Lexy J. 2007. Metode

Penelitian Kualitatif.

Bandung: Penerbit Rosda.

Pitrajaya, Hari. 2017. Fenomena Maraknya Aplikasi Berbagi Video di Indonesia. Jakarta: Arena 4G-LTE.

Pusat Penelitian Pengembangan Aplikasi Informatika dan Informasi dan Komunikasi Publik, Badan Penelitian dan Pengembangan Sumber Daya Manusia, Kementrian Komunikasi dan Informatika Republik Indonesia. 2017. Survey Penggunaan TIK 2017 serta Implikasinya terhadap Aspek Sosial Budaya Masyarakat. Jakarta.

Suyuti, S., 2015. Studi Perkembangan Teknologi 4G LTE dan WiMAX di Indonesia. Makasar: Universitas Muslim Indonesia.

Weatherburn, Peter, 2008. European Psychology Internet User Survey. London: Sigma Research. 